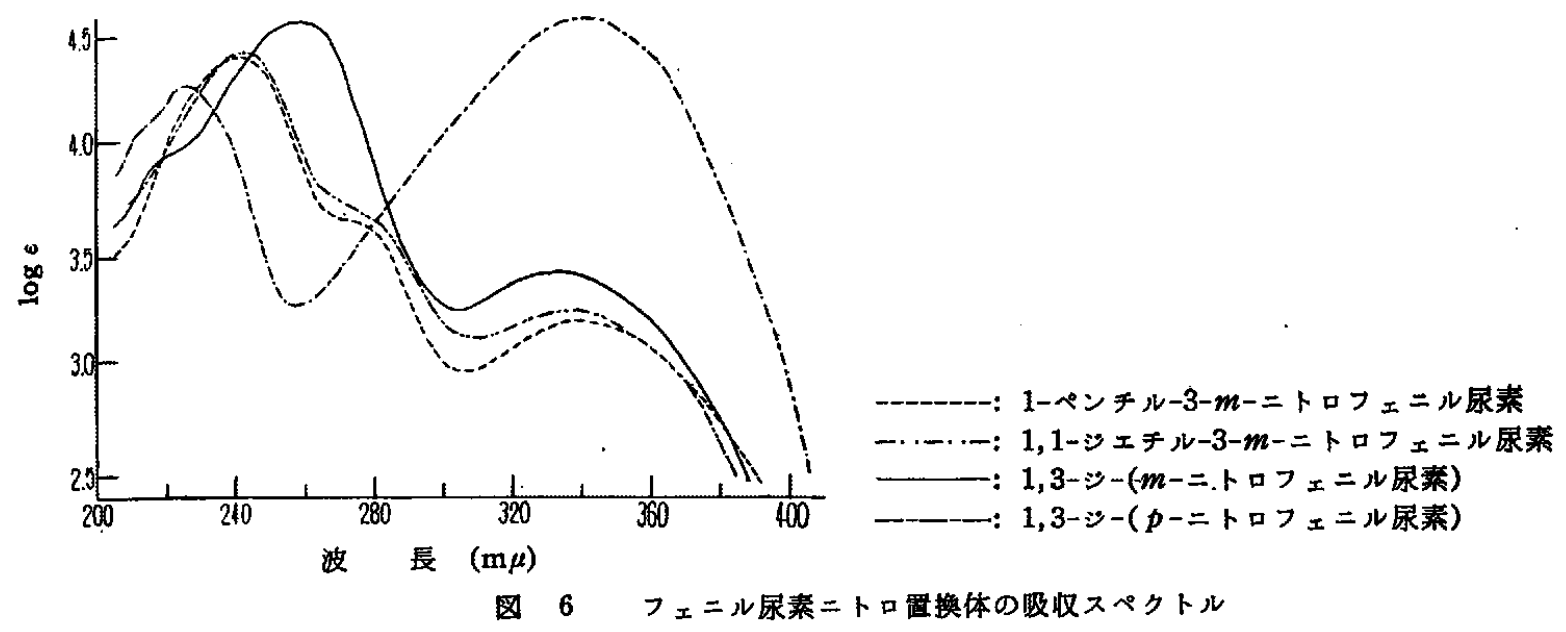

(1958 年 4 月, 日本化学会第 11 年会㴋演)

\title{
a-ケトプロピオン酸オキシマトービスジピリジルーコパルト(III) 過塩票酸醏の光学分割*1
}

(昭和 36 年 8 月 3 日受理)

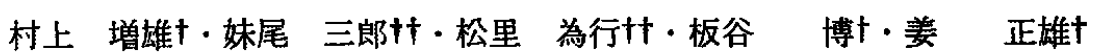

\footnotetext{
aーケトプロピオン酸オキシマトービスシピリシルーコバルト（I）過㙁素酸塩を光学分割した。てれはシピリシルの配位したコバ ルト鋠体では, 光学分割された唯一の例である。

$[\alpha]_{\mathrm{B}}^{30^{\circ}}+349^{\circ}\left(1 \mathrm{dm}, \mathrm{H}_{2} \mathrm{O}, c=0.21\right),[M]_{\mathrm{D}}^{30^{\circ}}+2000^{\circ}$

この物䆩は光学的に安定である。水溶渡中のラセ之化の速度は 1 次式䎲したがう。 $k_{\mathrm{rac}} \mathrm{e}^{30^{\circ}}=1.2 \times 10^{-4} \mathrm{~min}^{-1}$ 。 また，酸扰よびアルカりによってラセミ化の速度は大きくなる。 $k_{\mathrm{rac}^{30}}=2.9 \times 10^{-4} \mathrm{~min}^{-1}(1 \mathrm{~mol}$ 酢酸水溶液中)。 グリシノ（まだはアラニノ）ービスシピリシルーコバルト（鍇体の光学分割には成功しなかった。
}

\section{1 緒罟}

6 配位，八面体樥造の金属錯体はたがいに鏡像関係にある光学 異性体に分割された例があるり。不育炭素に基うく光学活性にく らべて，金属錯体による光学活性は，ラセミ化が容易に起り，旋 光度が大きい特徴がある。ジピリジルの配位した金属錯体の光学 分割は, 鉄, ニッケル鍇体の場合には成功しているが, コバルト 錯体の場合には成功していない2)。シピリジルに類似した構造の ヘーフェナンスロリンの場合には光学分割した報告りがある。

最近の動力学的研究によって, 錯体のラセ ミ化速度定数 $\left(k_{\mathrm{rac}}\right)$, 解蜼速度定数 $\left(k_{\mathrm{diss}}\right)$ と交換反度速度定数 $\left(k_{\mathrm{ex}}\right)$ が測定された。

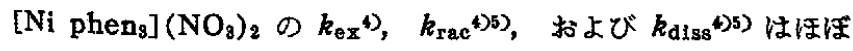

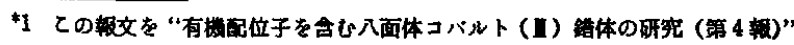
とする; 前報（第 3 報），村上，妹尾，松里，板谷，美，日化 83，741(1962)，

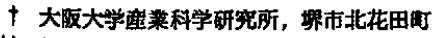

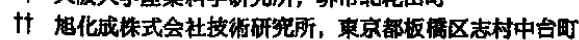

1) F. Basolo, Chem. Rev. 52, 459 (1953); The Chemistry of the Coördination Compounds, 308 (1956) New York.

2) P. Ellis, R. G. Wilkins, H. J. G. Williams, J. Chem. Soc. 1957, 4456.

3) F. M. Jaeger, Z. anorg. Chem. 170, 370 (1928); [Co en phen] $I_{3}$ 亿ついて朗䁍.

4) R. G. Wilkins, M. J. Williams, J. Chem. Soc. 1957, 1763.

5) F. Basolo, J. C. Hans, H. M. Newmann, J. Am. Chem. Soc. 73, 5102 (1953).
同じ值を示すために同じ擸構で反応が進行していることがわか った。 $\left[\mathrm{Ni} \mathrm{dipy}_{3}\right]^{2+} の k_{\mathrm{rac}}{ }^{6}$ と $k_{\mathrm{ex}}{ }^{536)}$ (はほぼ等しい。しかし [Fe phen $\left.]_{3}\right]^{2+} の k_{\mathrm{rac}^{7}}{ }^{7}, k_{\mathrm{diss}}{ }^{8)} た は\left[\mathrm{Fe} \mathrm{dipy}_{3}\right]^{2+} の k_{\mathrm{rac}^{7}}{ }^{7}$, $k_{\mathrm{diss}}$ \%) を測定して $k_{\mathrm{rac}}$ の異常に大きい事実から，分子内ラセミ 化説す提出された。 [Co dipy 3 ] $\mathrm{Cl}_{8}$ の $k_{\theta x}$ はCo (I) Kよる electron-transfer ${ }^{23}$ にっって大きくなるいう報告むある。しか し $k_{\text {ex }}$ はあまり大きくはない。 $k_{\mathrm{ex}}$ と $k_{\mathrm{rac}}$ はかならずしも一致 するとはかぎらなが, [Co dipys] ${ }^{3+}$ の光学分割代成功しない のは, $k_{\text {rac }}$ が大きいためとは思えない。

著者らは， $\alpha$-プロピオン酸オキシマトービスシピリジルーコバル 卜（I）錯体を合成して光学分割に成功した。オキシムのかわり にグリシンまたはアラニンの配位したジピリジルーコバルト（吉） 錯体の光学分割には成功しなかった。

\section{2 実臨および結果}

\section{1}

旋光度はD線についてはカール・ッァイス製ポーラリメーター

6) G. K. Schweitzer, J. M. Lee, J. Phys. Chem. 58, 195 (1952).

7) N. R. Davies, F. P. Dwyer, Trans. Faraday Soc. 48, 180(1953).

8) W. W. Brendt, D. K. Gullston, J. Am. Chem. Soc. 14, 3532 (1952).

9) J. H. Baxendale, P. George, Trans. Faraday Soc, 46, 55(1950). 
を用いて測定した。

\section{2 ジピリジルの合成}

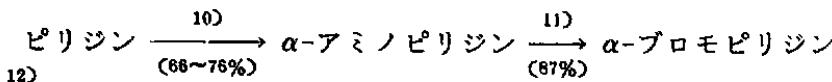

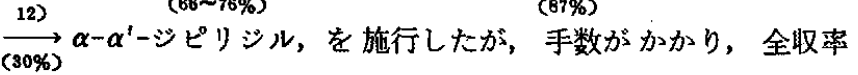
は20〜17\%で好ましい合成法ではなかった。

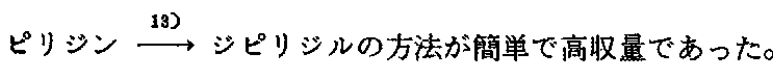
2.3

[Co $\left.\operatorname{dipy}_{2} \mathrm{CH}_{3} \mathrm{C}=(\mathrm{NO}) \cdot \mathrm{COO}\right] \mathrm{Cl}$.の合成法注既述した14)。

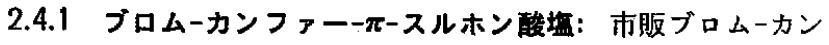
ファーールースルホン酸ーアンモニウム塩 $\left(\mathrm{C}_{10} \mathrm{H}_{14} \mathrm{O}_{4} \mathrm{BrSNH}_{4}\right)$ を水 加ら再結晶する。 $270^{\circ} \mathrm{C}$ 融解分解。 $[\alpha]^{22}+88.0 ，[M]_{D} 276^{\circ}$ 。

アンモニウム塩 $8.16 \mathrm{~g}$ 它水 $12 \mathrm{ml}$, エチルアルコール $6 \mathrm{ml}$ に加温溶解して，これに硝酸銀 $5.0 \mathrm{~g}$ 悠水 $3 \mathrm{ml}$ に溶かした液 を加える。かきまぜたのち，冷却すると銀垍 $8.8 \mathrm{~g}$ を得る。白色 針状結晶, mp $142^{\circ}$ 。

銀壏 $0.87 \mathrm{~g}(1 \mathrm{~mol})$ を水 $6 \mathrm{ml}$ に溶かし, [Co dipy ${ }_{2} \mathrm{CH}_{3} \mathrm{C}=$ (NO) $\mathrm{COO}] \mathrm{Cl} \cdot 5 \mathrm{H}_{2} \mathrm{O} 1.29 \mathrm{~g}(1 \mathrm{~mol})$ を水 $10 \mathrm{ml}$ に溶加した液 を加える。よくかきまぜたのち，遠心分離にようて沈殿を除き， 口液を減压 (10 mmHg) $30^{\circ} \sim 35^{\circ} \mathrm{C}$ で乾固する。収量 $1.70 \mathrm{~g}$ 。 水ーアルコール混液で再結晶。橙色針状結晶, $\mathrm{mp} 240^{\circ} \sim 241^{\circ} \mathrm{C}$ 。 分析値 $\mathrm{Co} 7.33 \%, \mathrm{Br} 9.94 \%, \mathrm{H}_{2} \mathrm{O} 2.44 \%$ $\left[\mathrm{Co}\left(\mathrm{C}_{10} \mathrm{H}_{8} \mathrm{~N}_{2}\right)_{2} \mathrm{C}_{3} \mathrm{H}_{3} \mathrm{O}_{3} \mathrm{~N}_{3}\right] \mathrm{C}_{10} \mathrm{H}_{14} \mathrm{O}_{4} \mathrm{BrS} \cdot \mathrm{H}_{2} \mathrm{O}$ としての

計算值 $\mathrm{Co} 7.47 \%, \mathrm{Br} 10.16 \%, \mathrm{H}_{2} \mathrm{O} 2.29 \%$

カンファ一塩を水, 水ーアルコール混液执よびニトロベンゼン を用いて，分別結晶をくり返したが $[\alpha]_{\mathrm{D}}^{19} 34^{\circ} \sim 40^{\circ} ，[M]_{\mathrm{D}}^{19} 260^{\circ}$ $\sim 307^{\circ}$ の間の旋光度を示して， カンファーの $[M]_{\mathrm{D}} 276^{\circ}$ にほ とんど近い。光学分割には失敗した。

2.4 .2 ๔-ケトプロピオン酸オキシマトービスジピリジルーコバ ルト（III)-ヨウ化物: 上記カンファー塩 $1.2 \mathrm{~g}$ をエルルルコ 一ル $18 \mathrm{ml}$ に溶かしてヨウ化カリウム $1.2 \mathrm{~g}$ を水 $2 \mathrm{ml}$ に溶加 した液を加える。混合後，暖めながらよくかきまぜていると， 結晶が析出する。暖いうちに口過する。 $0.95 \mathrm{~g}$ (95\% 収率)。水 $3.5 \mathrm{ml}$ とエチルアルコール $10 \mathrm{ml}$ に加温, 溶解して放置すると $0.67 \mathrm{~g}$ ，赤橙色針状結晶を得る。 $\mathrm{mp} 252^{\circ} \mathrm{C}$ (分解)。

分析值 Co $9.12 \%$, N 10.96\%, I $21.11 \%, \mathrm{H}_{2} \mathrm{O} 6.44 \%$ $\left[\mathrm{Co}\left(\mathrm{C}_{10} \mathrm{H}_{6} \mathrm{~N}_{2}\right)_{2} \mathrm{C}_{3} \mathrm{H}_{3} \mathrm{O}_{3} \mathrm{~N}\right] \mathrm{I} \cdot 2 \mathrm{H}_{2} \mathrm{O}$ としての

計算值 Co $9.36 \%, \mathrm{~N} 11.62 \%, \mathrm{I} 21.17 \%, \mathrm{H}_{2} \mathrm{O} 5.66 \%$ 2.5.1 アンチモニル酒石酸壏：埕酒石 $5.01 \mathrm{~g}$ を熱水 $35 \mathrm{ml}$ にとかし，これに硝酸銀 $2.55 \mathrm{~g}$ を水 $4 \mathrm{ml}$ にとかした液を加え る。ただちに結晶が析出する。暖いうちによくかきまぜて口過す る。沈殿怜水 $30 \mathrm{ml}$ で 3 回洗う。. 五酸化リンの入った乾燥器 中 3 日間放置。 $5.5 \mathrm{~g}$ (91\% 収率)。

\section{分析值 Ag 27.36\%}

[ $\left.\mathrm{C}_{4} \mathrm{H}_{2} \mathrm{O}_{2} \mathrm{SbAg}\right]$ としての計算值 $\mathrm{Ag} 27.36 \%$

この銀塩 $1.08 \mathrm{~g}(1 \mathrm{~mol})$ 熱水 $50 \mathrm{~m} l$ にできるだけ溶かして, オキシム錯塩 $\left[\mathrm{Co}\right.$ dipy $\left.\mathrm{C}_{3} \mathrm{H}_{3} \mathrm{O}_{3} \mathrm{~N}\right] \cdot \mathrm{Cl} \cdot 5 \mathrm{H}_{2} \mathrm{O} 1.5 \mathrm{~g}(1 \mathrm{~mol})$ を水

10) "Org. Reaction" 1, 99 (1942).

11) L. C. Craig, J. Am. Chem. Soc. 58, 232 (1934).

12) F. H. Burstall, J. Chem. Soc. 1838, 1662.

13) G. M. Badger, W. H. F. Sasse, J. Chem. Soc. London 1956, 616.

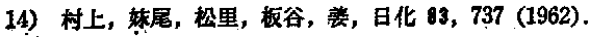

$15 \mathrm{ml}$ に溶かした液に加える。はげしく4 时間らりまぜる。塩化

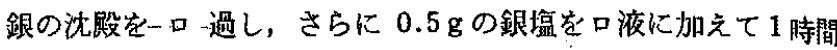
ふりまぜる(2 度めに加えた銀塭はほとんど回収される)。吸引口 過し，㖡它水浴上 $60^{\circ} \mathrm{C}$ 以下で減王濃縮して乾固する。水一工 チルアルコールの等量混合液 $6 \mathrm{ml}$ を加えて, $60^{\circ} \mathrm{C}$ に加温する。 不溶物をロ過して $2 \mathrm{ml}$ のエチルアルコールで洗う。品を液冷却 放置ずる上結晶が析出寸る。エチルアルコール $2 \mathrm{ml}$ で洗う。黄 褐他針状絬晶, $0.55 \mathrm{~g}$ 。口液に過剩(約 $30 \mathrm{ml}$ ) のエチルアルコ 一ルを加えると，さらに結晶が析出する。 $0.35 \mathrm{~g}$ 。残液を水浴上 $60^{\circ} \mathrm{C}$ 以下で減玨乾固寸る。赤褐色粉末 $0.95 \mathrm{~g}$ 。アンチモニル酒 石酸塩の全収量 $1.85 \mathrm{~g}$ (96\% 取率)。初めの結晶 $0.90 \mathrm{~g}$ を水 $2 \mathrm{ml}$, エチルアルコール $5 \mathrm{~m} l$ の混液に加温溶解して泠却すると, 黄橙色 プリズム状結晶を得る。五酸化リン中漧燥。 $\mathrm{mp} 254^{\circ} \mathrm{C}$ (分解) $0.82 \mathrm{~g}$ (取率 $42.5 \%$ )。

分析值 N $9.09 \%$

[Co $\left.\left(\mathrm{C}_{10} \mathrm{H}_{8} \mathrm{~N}_{2}\right)_{2} \mathrm{C}_{3} \mathrm{H}_{3} \mathrm{~N} \cdot \mathrm{O}_{8}\right] \mathrm{C}_{4} \mathrm{H}_{2} \mathrm{O}_{7} \mathrm{Sb}$ とての

$$
\text { 部算值 N } 9.11 \%
$$

$[\alpha]_{\mathrm{D}}^{23}+282^{\circ}\left(1 \mathrm{dm}\right.$ 管, $\left.\mathrm{H}_{2} \mathrm{O}, c=0.17\right)$

再結晶をいま 1 度くり返与と,

$[\alpha]_{\mathrm{D}}^{23}+283^{\circ}\left(1 \mathrm{dm}\right.$ 管, $\left.\mathrm{H}_{2} \mathrm{O}, c=0.21\right)$

$2.5 .2(+)-\boldsymbol{a}$-ケトプロピオン酸オキシマトービスジピリジルコバルト (III)-過塩絮酸塩: 光学活性のアンチモニル酒石酸塭 [Co dipy ${ }_{2} \mathrm{C}_{3} \mathrm{H}_{3} \mathrm{O}_{3} \mathrm{~N}_{3} \mathrm{C}_{4} \mathrm{H}_{2} \mathrm{O}_{7} \mathrm{Sb} \quad 0.8 \mathrm{~g}$ をエチルアルコール $12 \mathrm{ml}$ に溶かし，無水酶酸ナトリウム $0.2 \mathrm{~g}$ をエチルアルコール $2 \mathrm{ml}$ に溶かした液を加えると，ただちに白濁して沈尉が析出する。30 分間ふりまぜる。口過後，口液を水浴上 $40^{\circ} \sim 50^{\circ} \mathrm{C}$ で減圧乾固， 無水エチルアルコール $12 \mathrm{~m} l$ に溶かし, 過塩紫酸ナトリウム 0.2 $\mathrm{g}$ を水 $2 \mathrm{ml}$ に溶かした液を加える。 20 分間ふりまぜて沓冷す る。白色粉末含有の赤褐色結晶 $0.34 \mathrm{~g}$ を得る。水 $6 \mathrm{ml}$ で再結 晶すれば $0.15 \mathrm{~g}$ になる。初めの口液を濃縮してェチルアルコー ル $10 \mathrm{ml}$ を加えると結晶 $0.08 \mathrm{~g}$ を得る。計 $0.23 \mathrm{~g}$ (38\%取率)。 口液よりさらに $0.15 \mathrm{~g}$ 得たが不純である。五酸化リン中で乾燥。

分析値 Co $9.80 \%$, C $48.15 \%$, H $3.34 \%$ $\mathrm{N} 12.50 \%, \mathrm{Cl} 6.43 \%$

[Co $\left.\left(\mathrm{C}_{10} \mathrm{H}_{8} \mathrm{~N}_{2}\right)_{2} \mathrm{C}_{3} \mathrm{H}_{3} \mathrm{NO}_{3}\right] \mathrm{ClO}_{4}$ としての 計算檤 Co $10.30 \%$, C $48.31 \%$, H $3.53 \%$ N $12.25 \%, C 17.51 \%$

橙色, プリズム状結晶, $\mathrm{mp} 249^{\circ} \sim 250^{\circ} \mathrm{C}$ (分解)。 $[\alpha]_{\mathrm{D}}^{30}+349^{\circ}\left(2 \mathrm{dm}\right.$ 管, $\left.\mathrm{H}_{2} \mathrm{O}, c=0.115\right)$ $[M]_{\mathrm{D}}^{30}+1996^{\circ}$

\section{6 ラセミ化速度の海定}

$\mathrm{D}(+)\left[\mathrm{Co} \operatorname{dipy}_{2} \mathrm{CH}_{3} \mathrm{C}=(\mathrm{NO}) \mathrm{COO}\right] \mathrm{ClO}_{4}$ の $0.115 \%$ 水溶液を $2 \mathrm{dm}$ 管に入れて旋光度を測定した。 $\alpha+0.80^{\circ} ，[\alpha]_{\mathrm{D}}^{30}+349^{\circ}$ 。 $D(+)\left[\mathrm{Co} \mathrm{dipy}{ }_{2} \mathrm{CH}_{3} \mathrm{C}=(\mathrm{NO}) \mathrm{COO}_{\mathrm{C}} \mathrm{ClO}_{4}\right.$ K $1 \mathrm{~mol}$ 酷酸を加え て旋光度を測定した。

$$
\alpha+0.76^{\circ},[\alpha]_{D}^{30}+360^{\circ}\left(2 \mathrm{dm} \text { 管, } \mathrm{H}_{2} \mathrm{O}, c=1.07\right)
$$

$30^{\circ} \mathrm{C}$ の恒温に旋光管をたるち，12 時間ごとに旋光度をとれぞ れ測定した。 $\log \frac{a}{a-x}$ と時間の関係を（図 1) に示す。

[Co dipy $\left.{ }_{2} \mathrm{CH}_{3} \mathrm{C}=(\mathrm{NO}) \mathrm{COO}\right] \mathrm{SbO}-$ 酒石酸塩の 水溶液をつく り，室温に放置して旋光度を測定して図 1 亿示す。

$$
\alpha+0.98^{\circ}[\alpha]_{\mathrm{b}}^{19}+261^{\circ}\left(2 \mathrm{dm} \text { 管, } \mathrm{H}_{2} \mathrm{O}, c=0.187\right)
$$

室温は $19^{\circ} \pm 2^{\circ} \mathrm{C}$ であった。 
旋光度と時間の閶係は簡単な比例関係が成立しない。少なくと も二つの関係が得られた。ラセミ化反応林 1 次速度定数で表わさ れるが，直線が折れた形で表わされた。いずれの場合にもラセミ 化の初期の段階は非常に遅くて, 速度定数は錯体のイオン祳度の 0 次, 1 次, 2 次式のいずれにも適用できなかった。ラセミ化の速 度はある時間を境にして，急に大きくなる。この場合は 1 次反応 式で表わされる。したがって, 便宜上ラセミ化速度を 1 次反店で 表わす（図 1)。

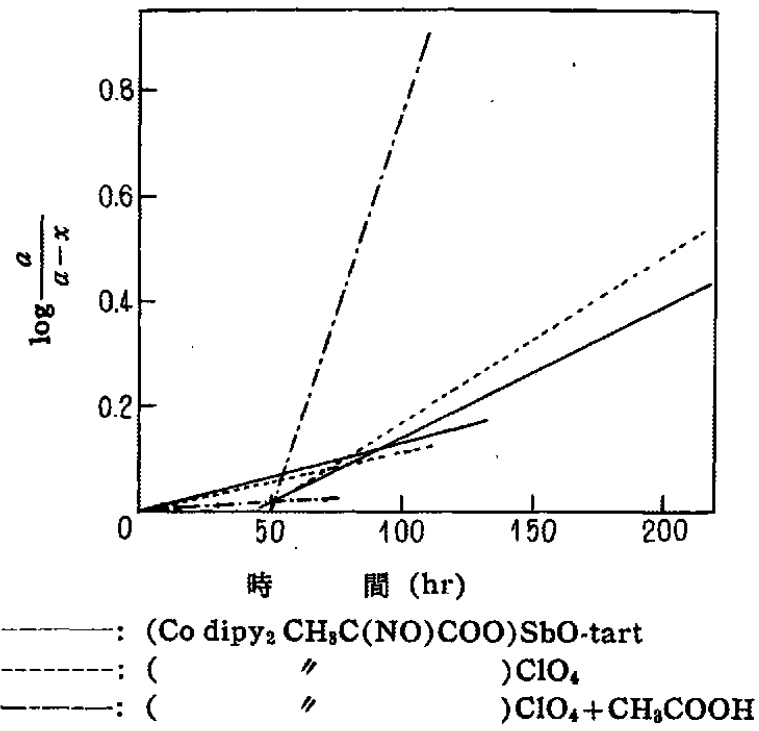

図1ラセミ化速度

ラセミ化の初期の過程を $k_{0}$, 後期の過程を $k_{1}$ で表わす。

[Co dipy ${ }_{2} \mathrm{CH}_{3} \mathrm{C}=(\mathrm{NO}) \cdot \mathrm{COO}$ ] $\mathrm{C}_{4} \mathrm{H}_{2} \mathrm{O}_{7} \mathrm{Sb}$ の $2.4 \times 10^{-3} \mathrm{~mol}$ 水 溶液のラセミ化速度定数は,
(半減期 242 時間)
$k_{0}=4.8 \times 10^{-5} \mathrm{~min}^{-1}$
(半诚期 112 時間)
$k_{1}=1.0 \times 10^{-4} \mathrm{~min}^{-1}$

である。

[Co dipy $\left.{ }_{2} \mathrm{CH}_{3} \mathrm{C}=(\mathrm{NO}) \mathrm{COO}\right] \mathrm{ClO}_{4} 2.0 \times 10^{-3} \mathrm{~mol}$ (水溶液) の 場合には,

(半減期 265 時間)

$k_{0}=4.4 \times 10^{-5} \mathrm{~min}^{-1}$

(半減期 95 時間)

$k_{1}=1.2 \times 10^{-4} \mathrm{~min}^{-1}$

である。

[Co dipy $\left.{ }_{2} \mathrm{CH}_{3} \mathrm{C}=(\mathrm{NO}) \mathrm{COO}\right] \mathrm{ClO}_{4} 1.9 \times 10^{-3} \mathrm{~mol}$ (水溶液) $\mathrm{K}$ 当モル酢酸を含有した場合には，

（半減期 894 時間） $k_{0}=1.3 \times 10^{-5} \mathrm{~min}^{-1}$

(半減期 40 時間) $\quad k_{1}=2.9 \times 10^{-4} \mathrm{~min}^{-1}$ である。

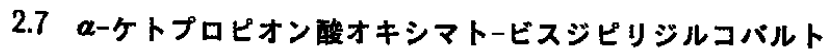

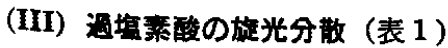

\section{8 アミノ酸錯体の分割}

グリシン（またはアラニン)ービスジピリジルコバルト（隹）塩 化物 ${ }^{15)}\left[\mathrm{Co} \operatorname{dipy}_{2} \mathrm{NH}_{2} \mathrm{CH}_{2} \mathrm{COO}\right] \mathrm{Cl}_{2}$, [Co dipy $\mathrm{NH}_{2} \mathrm{CH}\left(\mathrm{CH}_{3}\right)$ $\mathrm{COOJCl}_{2}$ のブロムーカンファースルホン酸塩およびアンチモニ ルー酒石酸塩をそれぞれ合成した。いずれも吸湿性粉末であって 分別結晶を試みたが，光学分割には成功しなかった。

\section{9 アミノ酸錯体の旋光度}

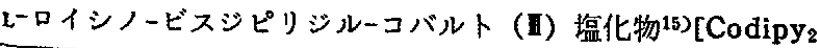

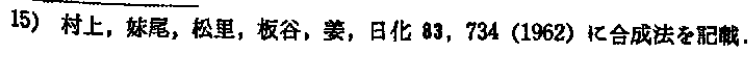

表 $1 \mathrm{D}(+)\left[\mathrm{Codipy}{ }_{2} \mathrm{CH}_{3} \mathrm{C}(\mathrm{NO}) \mathrm{COO}\right] \mathrm{ClO}$ 、の旋光分散

\begin{tabular}{|c|c|c|c|c|}
\hline$\stackrel{\lambda}{(\mathrm{m} \mu)}$ & $\left(10^{13} \sec ^{-1}\right)$ & $\alpha$ & {$[\alpha]_{D}^{16}$} & \\
\hline 690.8 & 43.4 & -0.021 & -157 & C \\
\hline 589.3 & 50.9 & & $(+350)$ & \\
\hline 579.1 & 51.8 & +0.138 & +1035 & C \\
\hline 546.1 & 54.9 & +0.319 & +1200 & B \\
\hline 491.6 & 61.0 & -0.126 & -945 & C \\
\hline 435.8 & 68.8 & -0.052 & -20 & B \\
\hline
\end{tabular}

注 $\mathrm{A}$ : 前速, $[\alpha]_{\mathrm{D}}^{30}$.

B: $2.67 \times 10^{-2} \%$ 水溶液.

C: $1.33 \times 10^{-2} \%$ 水溶液.

$1 \mathrm{dm}$ 管を用い $16^{\circ} \mathrm{C}$ でルドルフ精密分光光電旋光計 Model 200S-80 妾用いて則定した。

L-leucine $] \mathrm{Cl}_{2} \alpha-0.24^{\circ},[\alpha]_{\mathrm{D}}^{29}-93.4^{\circ}\left(1 \mathrm{dm}\right.$ 管, $\left.\mathrm{H}_{2} \mathrm{O}, c=0.22\right)$ レーチロジノービスジピリジルーコバルト（I）塩化物 ${ }^{15}$ [Codipy 2 L-tyrosine $] \mathrm{Cl}_{2} \alpha+0.09^{\circ},[\alpha]_{\mathrm{D}}^{2 \circ}+21.9^{\circ}\left(2 \mathrm{dm}\right.$ 管, $\mathrm{H}_{2} \mathrm{O}, c=$ $0.206 \%$ )

\section{3 考察}

3.1

トリスージピリジル錯体は，正八面体構造であるために(図 2) たがいに鏡像関係にある光学異性体がある。鉄20)21)，ニッケル錯 体かでは光学分割に成功しているが，コバルト錯体についてはま だ成功していない。 $\alpha$ ーケトプロピオン酸オキシマトービスシピリ ジルーコバルト（II）錯体の構造は, 赤外吸取スペクトルによる検 討によって確かめられたが，光学異性体が考えられる（図 3)。 $\alpha$ ープロピオン酸オキシムは 4 配位する場合と異なり，6 配位の場 合には, 二塩基性 2 配位とするために共鳴構造 I $\leftrightarrow$ I の関与が あって，平面構造をとると考えられる(図 4) ${ }^{16)}$ 。

$\left[\mathrm{Co} \mathrm{pn}_{3}\right] \mathrm{Cl}_{3}$ および $\left[\mathrm{Co} \mathrm{en} \mathrm{en}_{3}\right] \mathrm{Cl}_{3}$ ではそれぞれ 32 種類および 8 喠類の異性(体が考えられるが17)，この場合オキシムおよびシピ
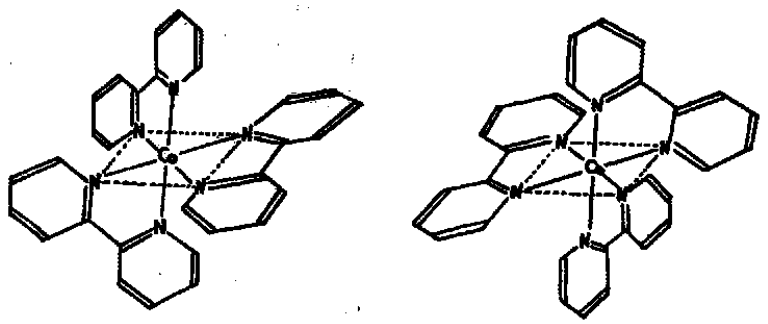

図 2 トリスージピリシル錯体の光学異性体
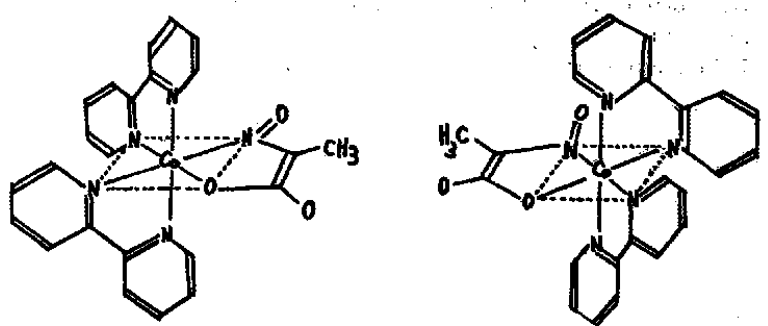

図 $3\left(\mathrm{Co} \mathrm{dipy}_{2} \mathrm{CH}_{3} \mathrm{C}=(\mathrm{NO}) \mathrm{COO}\right)+$ の光学異性体

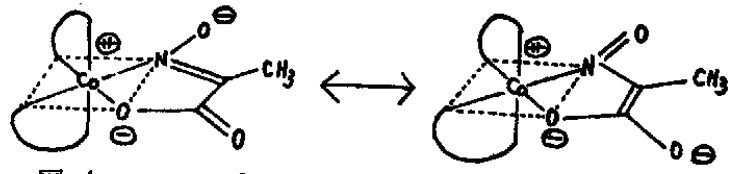

図4 4 -ケトプロピオン酸オキシムの共鳴構造式

16) 村上，姝尾，松里，板谷，美，日化 89，823 (1962).

17) E. J. Corey, J. C. Bailar, J. Am. Chem. Soc. 81, 2620 (1959). 
リジルが平面構造をとるために，ただ，2 種類の珙性体が考えら れるにすぎない。

ジピリジルと類似構造をしたフェナンスロリンの配位したコバ ルト錯体が光学分割されているが3)，著者らはジピリジルの配位 したコバルト錯体の光学分割に成功した。

\section{2}

金属錯化合物の旋光度は不斉炭素に基づくそれよりあ大きい。 表 2 に示す。

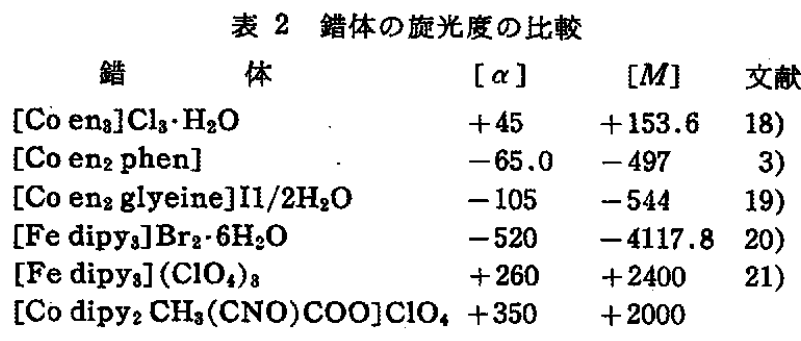

\section{3}

新しく分割された錯体の旋光分散を表 1 に示したが，この錯体 の第 1 吸収带は $650 \times 10^{-8} / \mathrm{sec}$ にある。旋光分散曲線を正稚に 描くこ亡はできないが，第 1 吸収帯の付近で旋光度は正 $\rightarrow$ 負へ变 わっており正のコットン効果を示している。

\section{4}

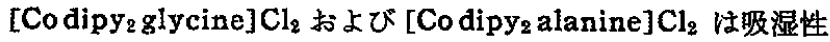
粉末であるために取り报いが困難であった。これらの光学分割に は失敗した。レーチロジンおよび を合成して旋光度を測定したが，光学分割されるオキシム錯体に くらべて旋光度が小さい。

\section{5}

最近, 動力学的研究によって, 交換反応速度, 解離速度とラ七
ミ化速度との関係が解明されるようになった（裴 3)。[Ni phen $\left(\mathrm{NO}_{3}\right)_{2}$ は $k_{0 \mathrm{x}}, k_{\mathrm{rac}}, k_{\mathrm{d} \text { iss }}$ が大体, 同じ値を示すために交換反 応, 解洞反応, ラセミ化反応も同じ譏棈で進むるのと考察された。 新しく合成された錯体の解離速度や交換速度が測定されていな いが, ラセこ化の 1 次定数は, 類似の鉄, ニッケル鍇体と近似し た值定示す。表 3 に要約している。

[Co dipy $]_{3} \mathrm{Cl}_{3}$ は一般法によって合成された場合の交換反心速 度の半減期は 150〜200 分である2。。交换反态速度は 2 価のコバ ルトイオンによって促進されて，2次反応速度式で示される。実 際, 磁気能率の測定により, 陚料には数パーセントの 2 価コバル トイオンの存在が確認された。[Co ens] $\mathrm{Cl}_{3}$ は合成の過程でほと んど 2 洒コバルトイオンの混入がないことも確かめられた。2 価 コバルトイオンによって反応が促進され，酸化削（酸素または 5 洒セシウムイオン）によって反応が娍速される事実から，CoI! CoIII間に電子移動が行なわれていると説明されている。

新しく合成した鍇体のラセミ化速度は，初期の 50～100洔間の 間は非常に遅い。として0次，1 次，2 次の速度式のいずれにも 決定でき難い。初期の速度は酸性側ほど遅い。ある時間を経過す るとラセミ化の速度は大となり，1 次反応速度を示すようにな る。この場合 $1 \mathrm{~mol}$ の酢酸を混入させると速度が 2 倍以上増大 する事実から，おそらく錯体の解傩に基づくものと思われる。便 宜上反応速度を 1 次速度定数で示した。 $k_{0}$ は電子移動に基ゔくう セミ化反応に起因すると推定するととすできるが今後に残された 課題である。[Co dipy $\left.{ }_{2} \mathrm{CH}_{3} \mathrm{C}=(\mathrm{NO}) \mathrm{COO}\right]^{+}$は光学分割される 安定な錯体であるが，なぜ [Co dipy $]_{3}^{3++}$ は光学分割できないの か。後者は合成の過程で Co(1) イオンの混入を防ぎ得ないのか。 本诈的に分割できないのか。今後に残された問題である。

（1959 年 4 月，日本化学会 第12 年会嘾演）

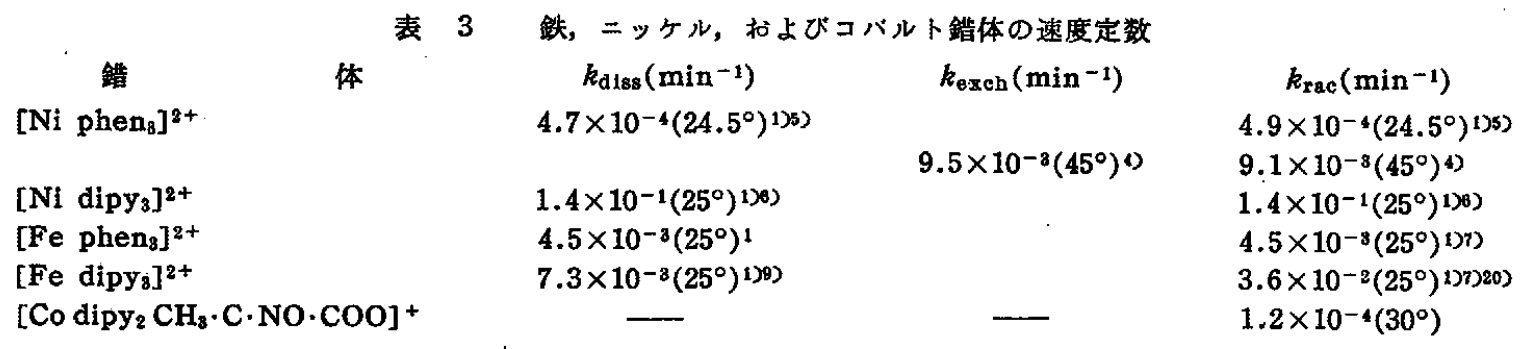

18) A. Werner, Ber. 45, 124 (1912); J. Mathieu, J. chim. phys. 33, 78 (1936)

19) J. Meisenheimer, Ann. 436, 226 (1924).
20) A. Werner, Ber. 45, 433 (1912).

21) F. P. Dwyer, B. C. Gyarfas, J. Am. Chem. Soc. 14, 4699 (1952). 